\title{
Free Movement of Albanian Goods within the European Union. New Challenges in the Context of Integration
}

\author{
Erjona Canaj, PhD \\ Lecturer, Faculty of Law \\ European University of Tirana, Albania \\ email: erjona.canaj@gmail.com erjona.canaj@uet.edu.al \\ Arjan Vasjari, PhD \\ Lecturer, Faculty of Law \\ European University of Tirana, Albania \\ email: vasjaria_al@yahoo.it
}

\section{Doi:10.5901/mjss.2013.v4n6p737}

\section{Abstract}

The free movement of goods is one of the success stories of the European project. It has helped to build the internal market from which European citizens and businesses are now benefiting and which is at the heart of EU policies. Today's internal market makes it easy to buy and sell products in 27 Member States. It gives consumers a wide choice of products and allows them to shop around for the best available offer. A properly functioning internal market for goods is thus a critical element for the current and future prosperity of the EU in a globalised economy. From a legal perspective the principle of the free movement of goods has been a key element in creating and developing the internal market and the Albanian market as well. In the context of the integration in the European Union, Albania has signed the Trade and Co-operation Agreement and the Stabilization and Association Agreement (SAA) with the European Union. Almost six years after the signature and the ratification of the SAA by all Member States, European Integration continues to be the paramount priority of the Republic of Albania. Albania is now fulfilling the criterion of membership in EU. Albania's reform agenda under the SAA is covering areas ranging from political dialogue and regional cooperation to Community freedoms in the movement of goods, services, workers and capital, and mutual co-operation in justice and home affairs. The aim of this paper is to introduce the public debate on free movement of Albanian's goods toward European Union, under SAA; articles 34-36 of the Treaty which define the scope and content of the principle by prohibiting unjustified restrictions on intra-EU trade and articles 16-45 SAA are on the focus of this study. In particular will be analyzed the free movement of goods, the harmonizing legislation, the actual rights and duties to be observed. In particular this paper will be focused on the jurisprudence of the ECJ and the Albanian Courts as well.

Key words: free movement, goods, Stabilization and Association Agreement, Albanian products.

\section{Introduction.}

The free movement of goods is one of the success stories of the European project. It has helped to build the internal market from which European citizens and businesses are now benefiting and which is at the heart of EU policies. Today's internal market makes it easy to buy and sell products in 27 Member States with a total population of more than 490 million. It gives consumers a wide choice of products and allows them to shop around for the best available offer. At the same time the free movement of goods is good for business. Around $75 \%$ of intra-EU trade is in goods. The single European marketplace that was created in past decades helps EU businesses to build a strong platform in an open, diverse and competitive environment. This internal strength fosters growth and job creation in the European Union and gives EU businesses the resources they need in order to be successful in other world markets. A properly functioning internal market for goods is thus a critical element for the current and future prosperity of the EU in a globalised economy ${ }^{1}$. The principle of the free movement of goods has been a key element in creating and developing the internal

1 See Communication from the Commission - The internal market for goods: a cornerstone for Europe's competitiveness [COM(2007) 35 final]. 
market and the Albanian market as well. In the context of the integration in the European Union, Albania has signed the Trade and Co-operation Agreement and the Stabilization and Association Agreement (SAA) with the European Union. Almost six years after the signature and the ratification of the SAA by all Member States, European Integration continues to be the paramount priority of the Republic of Albania. Albania is now fulfilling the criterion of membership in EU. Albania's reform agenda under the SAA is covering areas ranging from political dialogue and regional cooperation to Community freedoms in the movement of goods, services, workers and capital, and mutual co-operation in justice and home affairs.

\section{The role and importance of free movement of goods in the internal market. The general framework}

From a legal perspective the principle of the free movement of goods has been a key element in creating and developing the internal market. It is one of the economic freedoms established by the EC Treaty. Articles 28-30 of the EC Treaty defined the scope and content of the principle by prohibiting unjustified restrictions on intra-EU trade. Nowadays the internal market goes beyond these three Treaty articles. Harmonised legislation in many areas has specified the meaning of the internal market and has thereby framed the principle of the free movement of goods in concrete terms for specific products. Nevertheless, the fundamental function of the Treaty principle as a key anchor and safety net for the internal market remains unaltered. Many of the major restrictions on the free movement of goods have now been removed. The groundwork was done, along with the introduction of the single European market in 1993, but the continuous stream of complaints from citizens and businesses to the Commission underlines the fact that even the best efforts in the past have not removed all trade barriers. Small and medium-sized enterprises in particular still suffer from them. That is why these companies often prefer to concentrate their activities on a few individual Member States instead of the whole internal market, as they have difficulties in coping with different national rules on technical requirements for products that are not yet harmonised. Additionally, market access may be complicated by differences in retail or price regulations, with which businesses in other Member States are not familiar. At the same time, innovative new products and technological advances pose new challenges. A national regulatory environment which does not keep pace with such developments can soon hamper cross-border trade. Moreover, modern information technology, such as the Internet, facilitates crossborder shopping and increases the demand for quick and easy transfer of goods from one Member State to another. As a result, trade restrictions in certain areas that were not apparent in the past are now coming to light. However, the free movement of goods is not an absolute value. In specific circumstances certain overriding political aims may necessitate restrictions or even prohibitions which, while hampering free trade, serve important purposes such as protection of the environment or human health. Against a background of major global developments it comes as no surprise that a 'greening' of the free movement of goods has taken place in recent years, underlining the fact that certain grounds for justification may be viewed differently over time. It is thus a constant task, when applying EU law, to reconcile different, sometimes competing, goals and to ensure that a balanced, proportionate approach is taken. Today's free movement of goods incorporates many policies and fits smoothly into a responsible internal market which guarantees easy access to high-quality products, combined with a high degree of protection of other public interests.

The main Treaty provisions governing the free movement of goods are: Article 34 TFEU, which relates to intra-EU imports and prohibits quantitative restrictions and all measures having equivalent effect' between Member States; Article 35 TFEU, which relates to exports from one Member State to another and similarly prohibits 'quantitative restrictions and all measures having equivalent effect'; and Article 36 TFEU, which provides for derogations to the internal market freedoms of Articles 34 and 35 TFEU that are justified on certain specific grounds. The Treaty chapter on the prohibition of quantitative restrictions between Member States contains, also in Article 37 TFEU, rules on the adjustment of state monopolies of a commercial character. While Articles 34-36 TFEU laid the groundwork for the general principle of the free movement of goods, they are not the only legal yardstick for measuring the compatibility of national measures with internal market rules. These Treaty articles do not apply when the free movement of a given product is fully harmonised by more specific EU legislation, i.e. especially where the technical specifications of a given product or its conditions of sale are subject to harmonization by means of directives or regulations adopted by the EU. In some other cases, more specific Treaty rules, such as Article 110 TFEU on tax related provisions that may hamper the internal market, prevail over the general provisions of Articles 34-36 TFEU. Where secondary legislation is relevant, any national measure relating thereto must be assessed in the light of the harmonising provisions and not of those of the Treaty ${ }^{2}$. This is due to the fact that harmonising legislation can be understood as substantiating the free movement of goods principle by

2 Case C-309/02 Radlberger Getränkegesellschaft and S. Spitz [2004] ECR I-11763, paragraph 53. 
establishing actual rights and duties to be observed in the case of specific products. Therefore, any problem that is covered by harmonising legislation would have to be analysed in the light of such concrete terms and not according to the broad principles enshrined in the Treaty. Nevertheless, even after 50 years of dedicated activity on the part of the Community legislator in providing harmonised rules, the Treaty provisions on the free movement of goods have not become redundant; their scope is still remarkable. Either certain circumstances and/or products are not harmonised at all or they are only subject to partial harmonisation. In every instance in which harmonising legislation cannot be identified, Articles 34-36 TFEU can be relied on. In this respect the Treaty articles act as a safety net, which guarantees that any obstacle to trade within the internal market can be scrutinised as to its compatibility with EU law.

It is important to consider the secondary legislation as well: Directive 98/34/EC -laying down a procedure for the provision of information in the field of technical standards and regulations and of rules on information society services; Regulation (EC) No 2679/98 - The 'strawberry' regulation; Regulation (EC) No 764/2008 - The 'mutual recognition' regulation.

Since 1984, Directive 83/189/EEC, which has since become Directive 98/34/EC following codification, obliges the Member States of the European Union to notify the Commission and their counterparts of any draft technical regulation relating to products and, since 1999, to information society services before they are adopted in their national laws. The Commission and the Member States operate via a system of preventive control. During standstill periods, the Member States must refrain from adopting their notified draft regulations for at least three months while they are being examined. This period can be extended to up to 18 months where the measure in question is likely to create unjustified barriers to trade or where harmonisation work is in progress at EU level in the area covered by the notified draft. The procedure therefore eliminates any obstacles to the smooth functioning of the internal market before they even appear, thus avoiding retroactive action, which is always more burdensome. According to the case-law of the European Court of Justice (ECJ), any technical regulation which has not been notified at the draft stage or has been adopted during the mandatory standstill periods cannot be applied and thus enforced by national tribunals against individuals (see judgments CIA Security Internationa/ ${ }^{3}$ and Unilever ${ }^{4}$ ). This constant case-law has been confirmed again very recently on Schwibbert5.

Regulation (EC) No 2679/98 on the functioning of the internal market in relation to the free movement of goods among the Member States provides for special procedures to cope with serious obstacles to the free movement of goods among Member States which cause heavy loss to the individuals affected an require immediate action. Those obstacles may, for example, be the result of passivity of national authorities in the face of violent action by individuals or non-violent blockages of borders, or of action by a Member State, such as an institutionalised boycott of imported products. The regulation provides for an alert procedure

and for the exchange of information between Member States and the Commission. It also reminds Member States of their obligation to adopt necessary and proportionate measures to ensure the free movement of goods and to inform the Commission thereof, and it empowers the Commission to send a notification to the Member State concerned requesting that those measures be adopted within a very tight deadline ${ }^{6}$.

In 2008 the EU legislator adopted a regulation laying down the procedure relating to the application of certain technical rules to products lawfully marketed in another Member State: the Regulation (EC) No 764/2008 — The 'mutual recognition' regulation. The regulation places the burden of proof on the national authorities that intend to deny market access. They must set out in writing the precise technical or scientific reason for their intention to deny the product access to the national market. The economic operator is given the opportunity to defend its case and to submit solid arguments to the competent authorities. The regulation also establishes 'product contact points' in each Member State, which provide information about technical rules on products and the implementation of the mutual recognition principle to enterprises and competent authorities in other Member States.

\section{The Stabilisation and Association Agreement (2009-2012)}

On 18 February 2008 the Council adopted a new European partnership with Albania. The Stabilisation and Association Agreement (SAA) with the country was signed on 12 June 2006 and entered into force on 1 April 2009. It supersedes the

\footnotetext{
${ }^{3}$ Case C-194/94 CIA Security International [1996] ECR I-2201 and Case C-443/98.

4 Unilever [2000] ECR I-7535.

${ }^{5}$ Case C-20/05 Schwibbert [2007] ECR I-9447.

${ }^{6}$ For further info: $h$ ttp://ec.europa.eu/enterprise/policies/single-market-goods/free-movement-non-harmonised-sectors/rapid-interventionmechanism/index_en.htm
} 
Interim Agreement on trade and trade-related aspects (2006). The Stabilisation and Association Agreement creates a number of obligations such as establishment of a free trade area between the EU and its Member States and Albania. In this context, however, 'Member States' has been interpreted broadly to include all the authorities of a country, be they central authorities, the authorities of a federal state or any other territorial authorities ${ }^{7}$. The requirements laid down by articles 34-36 TFEU (and of SAA as well) apply equally to law-making, judicial or administrative bodies of a Member State $^{8}$. This evidently covers measures taken by all bodies established under public law as 'public bodies'. Although the term 'Member State' has been given a broad meaning, it does in general not apply to 'purely' private measures, i.e. measures taken by private individuals or companies'. Finally, by virtue of settled case-law, Article 34 TFEU applies also to measures adopted by the EU institutions. With regard to judicial review the EU legislature must, however, be allowed broad discretion. Consequently, the legality of a measure adopted can be affected only if the measure is manifestly inappropriate having regard to the objective which the competent institution is seeking to pursue ${ }^{10}$.

The Stabilisation and Association Agreement creates a number of obligations in the field of free movement of goods. It also provides for gradual alignment to EU technical regulations and standards as well as metrology, accreditation and conformity assessment procedures. Once the SAA became effective, the Stabilization and Association Council and the Stabilization and Association Committee has been set up. The Stabilization and Association Council (SAC) oversees the SAA implementation and examines any other major issue arising in its context. It is attended by members of the Council of European Union and EU Commission on one hand and members of the Albanian Government on the other (ministerial level). Albania's reform agenda under the SAA is notable, covering areas ranging from political dialogue and regional cooperation to Community freedoms in the movement of goods, services, workers and capital, and mutual co-operation in justice and home affairs. It requires extensive trade liberalization vis-à-vis both the EU and other countries in the region and provides for substantial non-tariff liberalization through the gradual harmonization with EU structures and directives in the areas of standards, certification, customs administration, competition, and intellectual property rights.

The key documents of the Albanian government in this context are: the National Strategy for Development and Integration (2007-2013) which establishes national strategic priorities and goals. The National Plan for the implementation of the SAA (2007-2013)11; the Action Plan addressing the Recommendations of the EC Opinion for Albania12. In 2007 Albanian Government adopted Action Plan for the Public Communication which define the government approach to inform and communicate with the public all the aspects of EU accession. The framework Law on standardisation was adopted in March 2008. The General Directorate of Standardisation (GDS), a government department reporting to the Minister of Economy, Trade and Energy, is responsible for standardisation in all fields except telecommunications. The GDS is a correspondent member of the International Organisation for Standardization (ISO), an associate member of the International Electrotechnical Commission (IEC) and an affiliate member of both the European Committee for Standardization (CEN) and the European Committee for Electrotechnical Standardisation (CENELEC). During 2010 the General Directorate of Standardisation (GDS) continued its preparations to apply for full membership of the European Committee for Standardization (CEN) and of the European Committee for Electrotechnical Standardization

\footnotetext{
7 Joined Cases C-1/90 and C-176/90 Aragonesa de Publicidad Exterior and Publivía [1991] ECR I-4151.

${ }^{8}$ Case 434/85 Allen \& Hanburys [1988] ECR 1245, paragraph 25; Case C-227/06 Commission v Belgium, (2008) ECR I-00046, paragraph 37.

9 The mere fact that a body is established under private law does not prevent the measures it takes from being attributable to the state. Indeed, the Court held that: - measures taken by a professional body which has been granted regulatory and disciplinary powers by national legislation in relation to its profession may fall within the scope of Article 34 TFEU; the activities of bodies established under private law but which are set up by law, mainly financed by the government or a compulsory contribution from undertakings in a certain sector and/or from which members are appointed by the public authorities or supervised by them can be attributed to the state. In a recent case, the Court even seemed to acknowledge that statements made publicly by an official, even though having no legal force, can be attributed to a Member State and constitute an obstacle to the free movement of goods if the addressees of the statements can reasonably suppose, in the given context, that these are positions taken by the official with the authority of his or her office. See Joined Cases 266/87 and 267/87 R v Royal Pharmaceutical Society of Great Britain [1989] ECR 1295; Case C-292/92 Hünermund and Others [1993] ECR I-6787; Case 249/81 Commission v Ireland (Buy Irish) [1982] ECR 4005; Case C-325/00 Commission v Germany [2002] ECR I-9977; Case C-470/03 AGM-COS.MET [2007] ECR I-2749.

10 Joined Cases C-154/04 and C-155/04 Alliance for Natural Health and Others [2005] ECR I-6451, paragraphs 47 and 52.

${ }^{11}$ Following the entry into force of the SAA on 1 April 2009, the government of Albania adopted the NPI for the implementation of SAA 2010-2014. This document sets out Albanian's short, medium and long priorities toward the process of EU integration.

12 This document was adopted on 10 June 2010 in order to address the 12 key priorities of EC opinion and formulate a systematic set of short-term measures which shall be implemented and monitored.
} 
(CENELEC) in 2012. The adoption of European standards (ENs) as Albanian standards continued to make progress. The number of ENs adopted is 17,442 , in line with the adoption rate of $95 \%$ set for 2011 . However, the number of standards translated remains low in comparison to the number of standards adopted, since most ENs have been adopted by the cover page method. The law on standardisation was amended in February 2011 to include the possibility of adopting and publishing standards prepared by the European Telecommunications Standards Institute (ETSI). The managing board of standardisation was established and became fully operational in November $2010^{13}$.

According to the European Commission, during 2011 there has been progress in the area of free movement of goods, particularly with regard to adopting EN standards as Albanian standards and in establishing the managing board of standardisation. Further efforts are still needed in order to harmonize Albanian legislation with the New and Old Approach directives, as well as to align the horizontal legislation with the acquis and to build up an adequate market surveillance infrastructure. Overall, preparations in this area are moderately advanced. The European Commission in its conclusions of 2012 established that: 'In the area of free movements of goods there has been progress as regards standartisation. Work needs to continue on legislative approximation of the acquis. An adequate market surveillance inspectorate is not yet in place. Preparations in this area are moderately advanced. ${ }^{114}$

In addition, at its fourth meting the SA Council (SAC) welcomed progress made by Albania in aligning its legislation and capacity with European standards and noted the satisfactory implementation of the Stabilisation and Association Agreement (SAA). It noted progress in aligning with EU standards in areas such as free movement of goods, SME policy, external relations and financial control while noting the need for further efforts in areas such as intellectual property law, information society, transport, energy and environment. The SA Council noted that Albania had adopted almost all the acquis on electronic communication services and networks in line with its SAA commitments. Further efforts are needed in the area of protection of intellectual and industrial property in order to make sure relevant SAA commitments are met. The strengthening of Albania's administrative capacity to effectively implement the SAA must continue ${ }^{15}$.

\section{The Free Movement of Goods under Title IV SAA}

The SA Agreement is being implementing progressively and shall be fully realised over a transitional period of a maximum of ten years, divided into two successive stages. (art. 6) But, the two stages it is not applied to Title IV, for which a specific schedule is laid down under that Title (art.7). The principle of free movement of goods means that products must be traded freely from one part of the Union to another (art.16-45 SAA). In a number of sectors this general principle is supplemented by a harmonised regulatory framework, following either the 'Old Approach' (laying down precise product specifications) or the 'New Approach' (setting general product requirements). Regarding the general principles, Albania needs to ensure that its legislation, including distinctly as well as indistinctly applicable measures, is compatible with Articles 34 to 36 of the Treaty on the Functioning of the European Union and related case law of the European Court of Justice, with special emphasis on the principle of mutual recognition ${ }^{16}$. Under the 'principle of mutual recognition', different national technical rules (e.g. relating to designation, form, size, weight, composition, presentation, labelling and packaging) continue to coexist within the internal market. The principle means that, notwithstanding technical differences between the various national rules that apply throughout the EU, Member States of destination cannot forbid the sale on their territories of products which are not subject to EU harmonisation and which are lawfully marketed in another Member State, even if they were manufactured according to technical and quality rules different from those that must be met by domestic products. The only exceptions to this principle are restrictions that are justified on the grounds described in Article 36 TFEU (protection of public morality or public security, protection of the health and life of humans, animals or plants, etc.) or on the basis of overriding requirements of general public importance recognized by the case-law of the Court of Justice, and are proportionate to the aim pursued. Thus, the mutual recognition principle in the non-harmonised area consists of a rule and an exception:

\footnotetext{
${ }^{13}$ European Commission Report (2011) p. 29-30.

${ }^{14}$ European Commission Report (2012) p. 5.

${ }^{15}$ See Fourth meeting of the Stabilisation and Association Council between Albania and the EU, Council of The European Union, 15 May, 2012.

${ }^{16}$ The principle originated in the famous Cassis de Dijon judgment of the Court of Justice of 20 February 1979 (Case 120/78 ReweZentral [1979] ECR 649) and was the basis for a new development in the internal market for goods. While at the beginning not expressly mentioned in the case-law of the Court of Justice, it is now fully recognised (see, for example, Case C-110/05 Commission v Italy [2009] ECR I-519, paragraph 34).
} 
- the general rule that, notwithstanding the existence of a national technical rule in the Member State of destination, products lawfully produced or marketed in another Member State enjoy a basic right to free movement, guaranteed by the TFEU;

- the exception that products lawfully produced or marketed in another Member State do not enjoy this right if the Member State of destination can prove that it is essential to impose its own technical rule on the products concerned based on the reasons outlined in Article 36 TFEU or in the mandatory requirements developed in the Court's jurisprudence and subject to the compliance with the principle of proportionality.

Until very recently, the most important problem for implementation of the mutual recognition principle was without any doubt the general legal uncertainty about the burden of proof. In 2008 the EU legislator adopted a regulation laying down the procedure relating to the application of certain technical rules to products lawfully marketed in another Member State: the Regulation (EC) No 764/2008 - The 'mutual recognition' regulation, repealing Decision No 3052/95/EC ${ }^{17}$.. The main objective of this regulation is to define the rights and obligations of national authorities and businesses when the former intend to deny mutual recognition and to refuse market access of a product lawfully marketed in another Member State. They must set out in writing the precise technical or scientific reason for their intention to deny the product access to the national market. The economic operator is given the opportunity to defend its case and to submit solid arguments to the competent authorities. Therefore, the Albanian institutions must take in consideration this regulation on mutual recognition.

In the area of horizontal measures, Albania adopted new legislation on accreditation, standardisation and metrology during 2007 and 2008. The Law on general product safety, essential requirements and conformity assessment of non-food products aims at gradual harmonisation with the principles of the New and Global Approach. It will need further revision to comply fully with the general principles of the New Approach and with the horizontal acquis adopted in $2008^{18}$. During 2011 there were positive developments in the legislative framework on accreditation and standardisation.

\section{a) The meaning of 'goods'}

Articles 34 and 35 TFEU and articles 16-45 SAA cover all types of imports and exports of goods and products. The range of goods covered is as wide as the range of goods in existence, so long as they have economic value: "by goods, within the meaning of the ... Treaty, there must be understood products which can be valued in money and which are capable, as such, of forming the subject of commercial transactions' ${ }^{\prime 1}$. In its rulings the Court of Justice has clarified on several occasions the proper designation of a particular product. Works of art must be seen as goods ${ }^{20}$. Coins which are no longer in circulation as currency would equally fall under the definition of goods, as would bank notes and bearer cheques $^{21}$, although donations in kind would not ${ }^{22}$. Waste is to be regarded as goods even when it is non-recyclable, but the subject of a commercial transaction. Electricity ${ }^{23}$ and natural gas ${ }^{24}$ count as goods, but television signals ${ }^{25}$ do not. The latter example underlines the fact that it can be legally important to draw a distinction between goods and services. While fish share certainly goods, fishing rights and angling permits are not covered by the free movement of goods principle, but constitute the 'provision of a service within the meaning of the Treaty provisions relating to the freedom to provide services ${ }^{26}$.

\section{b) Quantitative restrictions}

Quantitative restrictions have been defined as measures which amount to a total or partial restraint on imports or goods in transit ${ }^{27}$. Examples would include an outright ban or a quota system ${ }^{28}$, i.e. quantitative restrictions apply when certain

\footnotetext{
17 OJ L 218, 13.8.2008, p. 21.

${ }^{18}$ European Commission Report (2010) p. 50-52.

${ }^{19}$ Case 7/68 Commission $v$ Italy [1968] ECR 423.

20 Case 7/78 Thompson [1978] ECR 2247.

${ }^{21}$ Case C-358/93 Bordessa and Others [1995] ECR I-361.

${ }^{22}$ Case C-318/07 Persche [2009] ECR I-359, paragraph 29.

${ }^{23}$ Case C-393/92 Almelo v Energiebedrijf ljsselmij [1994] ECR I-1477.

${ }^{24}$ Case C-159/94 Commission v France [1997] ECR I-5815.

25 Case 155/73 Sacchi [1974] ECR 409.

${ }^{26}$ Case C-97/98 Jägerskiöld [1999] ECR I-7319.

${ }_{27}$ Case 2/73 Geddo [1973] ECR 865.
} 
import or export ceilings have been reached. The quantitative restriction are covert in primis by Article 34 TFEU and by a several articles of SAA such as Articles 18 par. $2^{29}, 19$, par. $3^{30} ; 21$, par. $2^{31}$ ecc. For example, according to article 26 SAA:

'On the date of entry into force of this Agreement, the Community shall abolish all quantitative restrictions and measures having equivalent effect on imports of agricultural and fishery products originating in Albania. 2. On the date of entry into force of this Agreement, Albania shall abolish all quantitative restrictions and measures having equivalent effect on imports of agricultural and fishery products originating in the Community.'

A quantitative restriction may be based on statutory provisions or may just be an administrative practice. Thus, even a covert or hidden quota system will be caught by Articles of the SAA and by Article 34 TFEU.

\section{c) Measures of equivalent effect}

The term 'measure having equivalent effect' is much broader in scope than a quantitative restriction. While it is not easy to draw an exact dividing line between quantitative restrictions and measures of equivalent effect, this is not of much practical importance given that the rules apply in the same way to quantitative restrictions as to measures of equivalent effect. As the same as the quantitative restriction, measures having equivalent effect is stated in several articles of the SAA. See for example articles 18, par.2; 19 par, 3; 21; 26; 27; 28; 33; 39. According to the measures having equivalent effect, the Albanian institutions, the national courts included, must have in consideration the consolidate jurisprudence of the Court of Justice. In Dassonville, the Court of Justice set out an interpretation on the meaning and scope of measures of equivalent effect32: 'All trading rules enacted by Member States which are capable of hindering, directly or indirectly, actually or potentially, intra- Community trade are to be considered as measures having an effect equivalent to quantitative restrictions.' This definition has been confirmed in the Court's case-law with minor variations. The term 'trading rules' does not usually appear nowadays, as the Dassonville formula is actually not limited to trading rules but also embraces, for instance, technical regulations.

Directive 70/50/EEC 33 , which formally applied during the Community's transitional period, stated the Commission's intention to catch not only measures which clearly accorded different treatment to domestic and imported goods, but also those which applied to them equally. Subsequently, in the Dassonville case, the Court stressed that the most important element determining whether a national measure is caught under Article 34 TFEU is its effect ('... capable of hindering, directly or indirectly, actually or potentially...'), therefore the discriminatory aspect of a measure is no longer the deciding factor for Article 34 TFEU. It seemed clear to the Court that not only overtly discriminatory measures could create barriers to trade in products between Member States.

The ruling by the Court in the Cassis de Dijon ${ }^{34}$ case affirmed the previous statements in Directive 70/50/EEC and Dassonville. By acknowledging that there might be differences between the national rules of the Member States and that this could inhibit trade in goods, the Court confirmed that Article 34 TFEU could also catch national measures which applied equally to domestic and imported goods. In this case, Member States could derogate by having recourse not only to Article 36 TFEU but also to the mandatory requirements, a concept which was first enshrined in this ruling. Therefore, it can be concluded that Article 34 TFEU will apply not only to national measures which discriminate against imported goods, but also to those which in law seem to apply equally to both domestic and imported goods, but in practice are more burdensome for imports (this particular burden stems from the fact that the imported goods are in fact required to comply with two sets of rules - one laid down by the Member State of manufacture, and the other by the Member State of importation). These rules are sometimes referred to as 'indistinctly applicable' (see Commission v Italy ${ }^{35}$ ). In

\footnotetext{
${ }^{28}$ Case 13/68 Salgoil [1968] ECR 453.

${ }^{29}$ According to art. 18, par. 2: 'Quantitative restrictions on imports into the Community and measures having equivalent effect shall be abolished on the date of entry into force of this Agreement with regard to products originating in Albania.'

${ }^{30}$ According to art. 19, par. 3:Quantitative restrictions on imports into Albania of goods originating in the Community and measures having equivalent effect shall be abolished upon the date of entry into force of this Agreement.'

${ }^{31}$ According to art. 21, par. 2: 'The Community and Albania shall abolish between themselves any quantitative restrictions on exports and measures having equivalent effect upon the date of entry into force of this Agreement.'

32 Case 8/74 Dassonville [1974] ECR 837.

${ }^{33}$ Directive 70/50/EEC on the abolition of measures which have an effect equivalent to quantitative restrictions on imports and are not covered by other provisions adopted in pursuance of the EEC Treaty (OJ L 13, 19.1.1970, p. 29).

${ }^{34}$ Case 120/78 Rewe-Zentral (Cassis de Dijon) [1979] ECR 649.

${ }_{35}$ Case C-110/05 Commission v Italy [2009] ECR I-519, paragraph 35.
} 
consequence, and following the Court's ruling in Dassonville and subsequently in Cassis de Dijon, there is no need for any discriminatory element in order for a national measure to be caught under Article 34 TFEU.

\section{d) Technical regulations containing requirements as to the presentation of goods (weight, composition, presentation, labeling, form, size, packaging)}

Requirements to be met by imported products as regards shape, size, weight composition, presentation, identification or putting up may force manufacturers and importers to adapt the products in question to the rules in force in the Member State in which they are marketed, for example by altering the labelling of imported products ${ }^{36}$. Given that such requirements as to the presentation of the goods are directly interlinked with the product itself, they are not considered to be selling arrangements, but as measures having equivalent effect according to Article 34 TFEU. In this context it is important to consider article 75 of the which establish that: '1. Albania shall take the necessary measures in order to gradually achieve conformity with Community technical regulations and European standardisation, metrology, accreditation and conformity assessment procedures. 2. To this end, the Parties shall start at an early stage:

- to promote the use of Community technical regulations, European standards and conformity assessment procedures;

- to provide assistance to fostering the development of quality infrastructure: standardisation, metrology, accreditation and conformity assessment;

- to promote the participation of Albania in the work of organisations related to standards, conformity assessment, metrology and similar functions (in particular CEN, CENELEC, ETSI, EA, WELMEC, EUROMET);

- where appropriate, to conclude European Conformity Assessment Protocols once the Albanian legislative framework and procedures are sufficiently aligned on those of the Community and appropriate expertise is available.'

In the European Union the following measures, for example, have been deemed contrary to Article 34 TFEU:

- $\quad$ a requirement for margarine to be sold in cubic packaging to distinguish it from butter ${ }^{37}$;

- a prohibition by a Member State on the marketing of articles made from precious metals without the requisite (official national) hallmarks 38 ;

- a prohibition on the marketing of videos and DVDs sold by mail order and over the Internet which do not bear an age-limit label corresponding to a classification decision from a higher regional authority or a national selfregulation body 39 .

\section{Albania's Case-law on free movement of goods}

The Court of Justice's case-law offers a clear guideline for the Albanian authorities in their future crafting and enactment of legal measures and administrative practices in the area of free movement of goods, as indeed more generally. As such, the case study presented in this article offers an illustration of the need for the proper approximation of (potential) candidate countries' existing legislation to that of the EU and of the effective implementation of the former in one of the key operative areas of the SAA ${ }^{40}$. For example, the ECJ rendered an interesting judgment in case C-456/10 Asociación Nacional de Expendedores de Tabaco y Timbre (ANETT) v Administración del Estado. The plaintiff requested annulment of Spanish law prohibiting tobacco retailers from importing tobacco, which allegedly was contrary to Article 34 TFEU. The latter prohibits quantitative restrictions and measures having equivalent effect. At the outset the Court rejected the argument of the Spanish government and of the European Commission that Article 37 TFEU (on monopolies) applies to this case. The Court of Justice held that by prohibiting tobacco retailers from directly importing tobacco products from other Member States, the Spanish legislation forced them to procure their supplies from authorised wholesalers. Such a procurement method was likely to present various disadvantages which the retailers would not encounter if they carried out the importation themselves. To this end the Spanish legislation constituted a measure having equivalent effect prohibited by Article 34 TFEU. In order to be justified such measures have fall under one of derogations listed in Article 36 TFEU or fall under mandatory requirements laid down in case-law of the Court of Justice. However, such measures

\footnotetext{
${ }_{36}$ Case C-33/97 Colim [1999] ECR I-3175, paragraph 37, and Case C-416/00 Morellato [2003] ECR I-9343, paragraphs 29 and 30.

${ }_{37}$ Case 261/81 Rau v De Smedt [1982] ECR 3961.

38 Case C-30/99 Commission v Ireland [2001] ECR I-4619.

${ }^{39}$ Case C-244/06 Dynamic Medien [2008] ECR I-505; in this judgment the trade barriers were, however, considered justified for reasons of the protection of minors.

40 Fjoralba Caka and Steven Blockmans, Implementing the Stabilisation and Association Agreement in Albania: Avoiding Discriminatory Practices in the Free Movement of Goods, European Journal of Law Reform, Volume 11, Issue 4, 2009, 511-530.
} 
must be appropriate for securing the attainment of an objective pursued and must be proportionate. All arguments submitted by the Spanish authorities were rejected and the Court of Justice held that the Spanish law was precluded by Article 34 TFEU.

This judgment should remain on the radar of Albanian authorities. Such measures are prohibited by free movement of goods acquis and this has to be taken into account when the Albanian legislation is screened as to compliance with EU law ${ }^{41}$.

In line with the orientation of the Court of Justice is the judgment of the Albanian Constitutional Court, Case no.24 dated 24.07.2009, the only one in the field of free movement of goods. The Court stated that the Albanian national legislation (Decision No.52, dated 14.01.2009 of the Council of Ministers) prohibits the marketing of Contents Diesel D2, while the case Diesel D1 allows its trading in certain specified quality conditions and applicable equally to all operators. The Decision is an exception to this prohibition only allowing trading of D2 Diesel fuel produced from refining crude oil extracted from oil fields in the territory of the Republic of Albania, as well as allowing trading case Diesel D1 produced by deposits within territory of the Republic of Albania in conditions most favorable quality than imported.

Consequently, the decision has created a situation of ban imports of a product and by favoring domestic products for another product.

The Constitutional Court concluded that the challenged decision was not taken in accordance with Article 42 of the SAA. Decision No.52, dated 14.01.2009 of the Council of Ministers is against the Stabilisation and Association Agreement, particularly on Articles 33 and 42 thereof. Consequently, the Constitutional Court considers that paragraphs $1,2,3,4,5,6,7,8,9$ and 11 of the above decision should be repealed.

\section{Conclusions}

In Albania there has been progress in the area of free movement of goods, particularly with regard to adopting EN standards as Albanian standards and in establishing the managing board of standardisation. Further efforts are still needed in order to harmonize Albanian legislation with the New and Old Approach directives, as well as to align the horizontal legislation with the acquis and to build up an adequate market surveillance infrastructure. The European Commission in its conclusions of this year established that: 'In the area of free movements of goods there has been progress as regards standartisation. Work needs to continue on legislative approximation of the acquis. An adequate market surveillance inspectorate is not yet in place. Preparations in this area are moderately advanced.' In addition, this year the SA Council (SAC) welcomed progress made by Albania in aligning its legislation and capacity with European standards and noted the satisfactory implementation of the Stabilisation and Association Agreement (SAA). It noted progress in aligning with EU standards in areas such as free movement of goods, SME policy, external relations and financial control while noting the need for further efforts in areas such as intellectual property law, information society, transport, energy and environment. The SA Council noted that Albania had adopted almost all the acquis on electronic communication services and networks in line with its SAA commitments. Further efforts are needed in the area of protection of intellectual and industrial property in order to make sure relevant SAA commitments are met. The strengthening of Albania's administrative capacity to effectively implement the SAA must continue.

At the other hand, the Court of Justice's case-law offers a clear guideline for the Albanian authorities in their future crafting and enactment of legal measures and administrative practices in the area of free movement of goods, as indeed more generally. As such, the ECJ case-law on free movement of goods offers illustrations of the need for the proper approximation of (potential) candidate countries' existing legislation to that of the EU and of the effective implementation of the former in one of the key operative areas of the SAA. These judgment should remain on the radar of Albanian authorities and has to be taken into account when the Albanian legislation is screened as to compliance with EU law.

\section{References}

\section{The European Court of Justice Case-law}

Case C-309/02 Radlberger Getränkegesellschaft and S. Spitz [2004] ECR I-11763

Case C-194/94 CIA Security International [1996] ECR I-2201

${ }^{41}$ http://curia.europa.eu/juris/d o c u m e $n t /$ d o c u m e $n t$. j s $f$ text=\&docid=122165\&pagelndex=0\&doclang=EN\&mode=/st\&dir= \&o cc=irst\&part=1\&cid=84527. See Adam Lazowski, Free movement of goods, in RECENT DEVELOPMENTS IN EU LAW EU Law Weekly, 2 May 2012, No 13/2012 
Case C-443/98 Unilever [2000] ECR I-7535

Case C-20/05 Schwibbert [2007] ECR I-9447

Joined Cases C-1/90 and C-176/90 Aragonesa de Publicidad Exterior and Publivía [1991] ECR I-4151.

Case 434/85 Allen \& Hanburys [1988] ECR 1245

Joined Cases 266/87 and 267/87 R v Royal Pharmaceutical Society of Great Britain [1989] ECR 1295;

Case C-292/92 Hünermund and Others [1993] ECR I-6787

Case 249/81 Commission v Ireland (Buy Irish) [1982] ECR 4005

Case C-325/00 Commission v Germany [2002] ECR I-9977

Case C-470/03 AGM-COS.MET [2007] ECR I-2749

Joined Cases C-154/04 and C-155/04 Alliance for Natural Health and Others [2005] ECR I-6451

Case 120/78 Rewe-Zentral [1979] ECR 649

Case C-110/05 Commission v Italy [2009] ECR I-519

Case 7/68 Commission v Italy [1968] ECR 423.

Case 7/78 Thompson [1978] ECR 2247.

Case C-358/93 Bordessa and Others [1995] ECR I-361

Case C-318/07 Persche [2009] ECR I-359, paragraph 29.

Case C-393/92 Almelo v Energiebedrijf ljsselmij [1994] ECR I-1477.

Case C-159/94 Commission v France [1997] ECR I-5815.

Case 155/73 Sacchi [1974] ECR 409.

Case C-97/98 Jägerskiöld [1999] ECR I-7319.

Case 2/73 Geddo [1973] ECR 865.

Case 13/68 Salgoil [1968] ECR 453

Case 8/74 Dassonville [1974] ECR 837.

Case 120/78 Rewe-Zentral (Cassis de Dijon) [1979] ECR 649

Case C-110/05 Commission v Italy [2009] ECR I-519

Case C-33/97 Colim [1999] ECR I-3175

Case C-416/00 Morellato [2003] ECR I-9343

Case 261/81 Rau v De Smedt [1982] ECR 3961

Case C-30/99 Commission v Ireland [2001] ECR I-4619

Case C-244/06 Dynamic Medien [2008] ECR I-505

European Commission Report (2010) fq. 5-52

European Commission Report (2011) fq. 29-30

European Commission Report (2012) fq. 5-6

Stabilisation and Association Agreement (SAA) of 12 June 2006

National Strategy for Development and Integration (2007-2013 which establishes national The National Plan for the implementation of the SAA (2007-2013)

Action Plan for the Public Communication (2007)

Laurence W. Gormley, (2009) EU Law of free movement of goods, Oxford University Press.

Peter Olivers, (2010) Oliver on Free Movement of Goods in the European Union, Hart.

Lorna Woods, (2004) Free Movement of Goods and Services Within the European Community, European Business Law Library.

P.Craig, P.Ge Burca, (2011) EU Law, Text Cases and materials.

Giuseppe Tesauro (2010), II diritto dell'Unione Europea.

Fjoralba Caka and Steven Blockmans,(2009) Implementing the Stabilisation and Association Agreement in Albania: Avoiding Discriminatory Practices in the Free Movement of Goods, European Journal of Law Reform, Volume 11, Issue 4, 2009, 511-530.

Adam Lazowski (2012), Free movement of goods, in Recent Developments in EU Law, 2 May 2012, No 13/2012. 